\title{
Faktor-Faktor yang Mempengaruhi Kualitas Permukiman Pasca Gempa Bumi Di Kecamatan Pleret Kabupaten Bantul
}

\author{
The Influencing Factors Of Housing Quality Post-Earthquake \\ In Pleret Subregency, Bantul Regency
}

\section{Sri Rum Giyarsih ${ }^{1}$ dan Syarifah Aini Dalimunthe ${ }^{2}$}

Diterima: 6 Desember 2012 Disetujui: 30 januari 2013

\begin{abstract}
Abstrak: Penelitian ini dilakukan di Kecamatan Pleret Kabupaten Bantul dengan mengambil sampel di Desa Wonokromo dan Desa Wonolelo. Kecamatan Pleret merupakan kecamatan dengan tingkat kerusakan permukiman tertinggi di Kabupaten Bantul akibat gempabumi tahun 2006. Penelitian ini bertujuan untuk memahami faktor-faktor yang mempengaruhi kualitas permukiman pasca gempabumi di daerah penelitian. Metode yang digunakan adalah metode survai dengan wawancara terstruktur terhadap 60 responden di kedua desa tersebut serta wawancara mendalam terhadap informan kunci. Teknik pengolahan dan analisis data dilakukan dengan metode statistik inferensial dan deskriptif kualitatif. Penelitian ini menemukan bahwa terdapat perbedaan kualitas permukiman di kedua desa tersebut setelah gempabumi. Perbedaan kualitas permukiman tersebut dipengaruhi oleh faktor internal dan faktor eksternal. Faktor internal berupa status sosial ekonomi penduduk mempunyai peran dalam mempengaruhi perubahan kualitas permukiman di Desa Wonokromo. Sementara itu faktor eksternal yang berupa bantuan finansial untuk rehabilitasi dan rekonstruksi permukiman mempunyai peranan yang signifikan dalam mempengaruhi perubahan kualitas permukiman di Desa Wonolelo.
\end{abstract}

Kata-kata kunci : faktor pengaruh, kualitas permukiman, pasca gempa bumi

\begin{abstract}
This research was conducted in Pleret Subregency, Bantul Regency, specifically in Wonokromo and Wonolelo Village. This subregency had the highest housing destruction in Bantul Regency due to earthquake in 2006. This research aimed to understand the influencing factors of housing quality post-earthquake in the research area. Method used was survey method i.e. structured interview with 60 respondents in both villages and in-depth interview with key informants. Data was processed and analyzed inferentially statistic and qualitative descriptive. The result of this research is a difference in housing quality in both villages after earthquake. This difference occurs under the influence of internal and external factors. Internal factor includes citizen's social and economic status which takes role in housing quality change in Wonokromo Village. Meanwhile, external factors involve financial support for housing rehabilitation and reconstruction which significantly influence the housing quality change in Wonolelo Village.
\end{abstract}

Keywords: influencing factor, housing quality, post-earthquake

\footnotetext{
${ }^{1}$ Program Studi Geografi dan Ilmu Lingkungan Fakultas Geografi UGM

Sekip Utara Jalan Kaliurang, Bulaksumur, Yogyakarta, 55281

${ }^{2}$ Peneliti BBC Media Action Indonesia
} 


\section{Pendahuluan}

Peristiwa gempa bumi yang terjadi 27 Mei 2006 telah menimbulkan korban dan dampak kerusakan yang cukup besar. Kerusakan yang paling parah terjadi di wilayah Kabupaten Bantul dan Kabupaten Klaten. Berdasarkan data Direktorat Jendral Penataan Ruang Departemen Pekerjaan Umum tanggal 25 Juli 2006, terdapat sejumlah 302.868 rumah rusak yang tidak dapat dihuni dan sejumlah 252.909 rumah rusak yang masih bisa dihuni.

Gempa bumi sebagai fenomena alam menimbulkan dampak kerusakan dan hilangnya tempat tinggal. Proses rehabilitasi dan rekonstruksi yang dilakukan terhadap gempa bumi di Kabupaten Bantul selain fokus pada kegiatan pemulihan fasilitas umum juga tidak mengabaikan pentingnya perbaikan fasilitas permukiman dalam skala mikro. Tahapan rehabilitasi dan rekonstruksi permukiman melibatkan LSM dari dalam maupun luar negeri serta pemerintah daerah. Besar bantuan yang diterima oleh masyarakat cenderung bervariasi. Selain dana yang diterima dari pihak donor, masyarakat juga berusaha secara swadaya untuk melakukan rehabilitasi dan rekonstruksi pasca gempa. Keadaan ini memicu munculnya perubahan kualitas permukiman pasca gempa bumi yang akhirnya menjadi kajian yang menarik untuk diteliti lebih lanjut tentang faktor-faktor yang mempengaruhi kualitas permukiman tersebut.

Pada saat ini semakin banyak pihak yang menaruh perhatian pada modal sosial dalam proses recovery pasca bencana. Modal sosial telah dikaji dalam berbagai tataran mulai dari filosofi, teori dan pengertian, operasional desain, implementasi dan monitoring serta evaluasi dari praktek aktivitas-aktivitas modal sosial yang dibentuk dan dilembagakan oleh warga masyarakat lokal. Penelitian yang dilakukan oleh Sakamoto dan Yamori (2009) di Patalan dan Nglepen Yogyakarta misalnya, menyebutkan bahwa modal sosial bervariasi di setiap wilayah. Pada masa pemulihan awal pasca gempa bantuan dari donor maupun pemerintah tidak banyak mempengaruhi kondisi korban gempa di Kabupaten Bantul. Manifestasi modal sosial yang ada dalam masyarakat merupakan bagian penting dalam tahapan ini. Penelitian tersebut mengungkapkan keberadaan kelompok masyarakat (pokmas), gotong royong, dan arisan mempercepat proses pemulihan kondisi sosial ekonomi masyarakat termasuk rehabilitasi dan rekonstruksi permukiman di Kabupaten Bantul pasca gempa bumi.

Tujuan penelitian ini adalah untuk memahami faktor-faktor yang mempengaruhi kualitas permukiman pasca gempabumi di daerah penelitian. Ada dua manfaat yang diharapkan dari penelitian ini, yaitu dari sisi teoretis dan praktis empiris. Dari sisi teoretis penelitian ini akan memperkaya hasil-hasil penelitian tentang faktor-faktor yang mempengaruhi kualitas permukiman pasca bencana. Dari sisi praktis empiris, hasil penelitian ini bermanfaat sebagai landasan berpijak dalam membangun kerangka pikir dan perumusan kebijakan pembangunan wilayah khususnya bidang permukiman.

\section{Metode Penelitian}

Penelitian ini dilakukan di dua desa, yaitu Wonokromo dan Wonolelo, Kecamatan Pleret Kabupaten Bantul dengan pertimbangan-pertimbangan sebagai berikut:

(1) Kecamatan Pleret merupakan kecamatan yang memiliki tingkat kerusakan rumah terparah akibat gempa bumi di Kabupaten Bantul (Daryono, 2012; Suryanto, 2012).

(2) Unit analisis administrastif digunakan sebagai wilayah penelitian karena pertimbangan kemudahan untuk pengumpulan data, koordinasi penelitian, maupun pengurusan ijin penelitian. 
Pada tahap awal dipilih dua desa yaitu Wonokromo dan Wonolelo di Kecamatan Pleret yang memiliki tingkat kerusakan rumah terparah akibat gempa. Untuk selanjutnya seluruh rumah tangga yang mengalami kerusakan rumah di desa tersebut dijadikan populasi penelitian.

Tidak keseluruhan rumah tangga yang mengalami kerusakan rumah di desa tersebut diambil sebagai responden, namun hanya sebagian yang dijadikan sebagai sampel. Teknik pengambilan sampel dilakukan dengan metode acak sederhana dengan pertimbangan: (1) populasi bersifat seragam dalam hal mengalami kerusakan rumah, dan (2) responden tidak tersebar secara geografis. Dari sejumlah populasi yang ada diambil sebanyak 60 responden dengan pertimbangan: (1) karena sifatnya yang seragam maka dengan mengambil 60 responden dianggap sudah dapat mewakili populasi yang ada, dan (2) dengan mengambil 60 responden sudah memenuhi syarat untuk uji statistik inferensial karena distribusinya normal.

Selain metode kuantitatif, penelitian ini juga dilengkapi dengan informasi kualitatif agar mampu mengungkap secara mendetail mengenai fungsi social capital pada kedua desa yang menjadi wilayah penelitian. Dengan demikian penelitian ini akan mampu memberikan pemahaman tentang pola pikir dan tindakan masyarakat dalam kegiatan rehabilitasi dan rekonstruksi permukiman. Untuk mengungkap hal tersebut, dikumpulkan data melalui wawancara mendalam terhadap beberapa informan.

Langkah selanjutnya adalah mengolah dan menganalisis data. Untuk mengetahui faktor-faktor yang mempengaruhi kualitas permukiman dalam perspektif kuantitatif dilakukan dengan analisis statistik inferensial yang berupa uji regresi linear berganda. Untuk memperoleh pemahaman tentang peran modal sosial dalam rehabilitasi dan rekonstruksi permukiman dilakukan dengan analisis deskriptif kualitatif.

\section{Hasil Dan Pembahasan}

Faktor yang mempengaruhi kualitas permukiman dalam penelitian ini ditelaah dalam dua perspektif. Pertama adalah perspektif kuantitatif dengan melihat faktor yang mempengaruhi kualitas permukiman ditinjau dari hasil pengumpulan data melalui kuesioner, dengan model pertanyaan tertutup. Kedua, adalah perspektif kualitatif dengan melihat peran modal sosial dalam proses pembangunan kembali permukiman pasca gempa.

\section{Faktor-Faktor Yang Mempengaruhi Kualitas Permukiman Dalam Perspektif Kuantitatif}

Sesuai dengan tujuan penelitian untuk mengetahui faktor-faktor yang mempengaruhi kualitas permukiman pasca gempa, maka pada tahap awal data primer yang telah diperoleh dari variabel-variabel kualitas permukiman digabungkan menjadi variabel komposit yang menggambarkan kualitas permukiman. Dalam penelitian ini selanjutnya kualitas permukiman dikategorikan menjadi tiga yaitu rendah, sedang, dan tinggi. Dari data yang peroleh kualitas permukiman rendah memiliki skor <60, kualitas permukiman sedang memiliki skor 60-75 dan permukiman dengan kategori kualitas permukiman tinggi memiliki skor $>75$ (Lihat Tabel 1).

Dari Tabel 1 dapat dicermati bahwa di Desa Wonokromo dan Desa Wonolelo menunjukkan perbedaan kualitas permukiman pra dan pasca gempabumi. Di satu sisi di Desa Wonokromo mengalami peningkatan jumlah kualitas permukiman yang rendah. Sementara itu untuk kualitas permukiman yang sedang mengalami penurunan dan untuk kualitas permukiman tinggi tidak mengalami perubahan. Di sisi lain di Desa Wonolelo terjadi penurunan jumlah permukiman kualitas rendah dan terjadi peningkatan jumlah permukiman kualitas sedang dan tinggi. 
Tabel 1. Kualitas Permukiman di Desa Wonokromo dan Desa Wonolelo Tahun 2010

\begin{tabular}{lllllllll}
\hline Kategori & \multicolumn{3}{c}{ Desa Wonokromo } & \multicolumn{3}{c}{ Desa Wonolelo } \\
Kualitas & \multicolumn{2}{c}{ Sebelum } & \multicolumn{2}{c}{ Setelah } & \multicolumn{2}{c}{ Sebelum } & \multicolumn{2}{c}{ Setelah } \\
Permukiman & Jumlah & Persen & Jumlah & Persen & Jumlah & Persen & Jumlah & Persen \\
\hline $\begin{array}{l}\text { Rendah } \\
\text { Skor }<60\end{array}$ & 14 & 46,7 & 17 & 56,7 & 25 & 83,3 & 20 & 67,0 \\
$\begin{array}{l}\text { Sedang } \\
\text { Skor } 60-75\end{array}$ & 12 & 40,0 & 9 & 30,0 & 3 & 10,0 & 6 & 20,0 \\
$\begin{array}{l}\text { Tinggi } \\
\text { Skor }>75\end{array}$ & 4 & 13,3 & 4 & 13,3 & 2 & 6,7 & 4 & 13,0 \\
\hline
\end{tabular}

Sumber : Data Primer, 2010

Dari sisi fisiografi Desa Wonokromo merupakan desa yang terletak pada elevasi yang lebih rendah, sedangkan Desa Wonolelo terletak pada elevasi yang lebih tinggi. Dari sisi aksesibilitas fisik wilayah Desa Wonokromo memiliki tingkat aksesibilitas fisik wilayah yang lebih tinggi dari pada Desa Wonolelo.

Desa Wonokromo terletak berdekatan dengan ibukota Kecamatan Pleret. Dengan demikian desa ini sekaligus dipostulasikan mempunyai akses yang lebih baik terhadap pelayanan fasilitas sosial ekonomi dari pada Desa Wonolelo. Fakta empiris di lapangan juga menunjukkan bahwa di Desa Wonokromo ini kondisi sosial ekonomi penduduk juga relatif lebih tinggi dari pada penduduk di Desa Wonolelo.

Temuan penelitian ini tidak sejalan dengan teori-teori dan hasil-hasil penelitian terdahulu. Beberapa penelitian terdahulu seperti yang dilakukan oleh Yunus (1989), Ritohardoyo (2000), Primayodanti (2008), Romadhona (2008), Solikhah dan Larasati (2008), dan Syahyudesrina (2008) menemukan bahwa kualitas permukiman berkorelasi positif dengan status sosial ekonomi misal pendapatan dan pendidikan.

Di daerah penelitian ditemukan bahwa di Desa Wonokromo yang memiliki status sosial ekonomi lebih tinggi dari pada Desa Wonolelo seharusnya juga memiliki kualitas permukiman yang lebih baik dari pada di Desa Wonolelo seperti halnya dengan temuan dalam beberapa penelitian terdahulu. Namun fakta empiris di lapangan menunjukkan bahwa di Desa Wonolelo lebih banyak penduduk yang mengalami peningkatan kualitas permukiman setelah gempabumi

Hal ini disebabkan adanya faktor lain yang turut mempengaruhi proses pembangunan (rehabilitasi dan rekonstruksi) permukiman di kedua desa tersebut selain karakteristik sosial ekonomi pendudukya. Faktor lain yang dimaksud dalam penelitian ini adalah adanya faktor eksternal yang berasal dari luar yang berupa intervensi dari pihak luar yang berujud bantuan finansial. Dengan demikian, dalam konteks kejadian bencana terdapat hubungan yang tipikal antara kualitas permukiman dengan faktor eksternal yang berupa bantuan finansial.

Dari sisi tingkat kerusakan permukiman akibat gempa bumi, Desa Wonolelo mengalami kerusakan yang lebih parah dari pada permukiman di Desa Wonokromo. Dari hasil wawancara mendalam dengan informan kunci juga terungkap bahwa bantuan finansial untuk rehabilitasi dan rekonstruksi permukiman lebih banyak diterima oleh penduduk Wonolelo dari pada penduduk Wonokromo.

Dari hasil wawancara mendalam dengan informan kunci juga dapat diketahui bahwa sebagian besar penduduk Desa Wonokromo memperoleh bantuan dari pemerintah untuk rehabilitasi dan rekonstruksi permukiman. Sementara itu sebagian besar penduduk Desa 
Wonolelo menerima bantuan dari LSM. Besar dana bantuan yang dikucurkan oleh pemerintah ini bervariasi mulai dari Rp. 1.000.000 sampai Rp. 15.000.000 tergantung tingkat kerusakan permukiman. Di sisi lain bantuan yang berasal dari LSM relatif lebih besar misal yang berasal dari JRF (Java Reconstruction Fund) sebesar Rp. 20.000.000.

Dari hasil temuan penelitian ini sekaligus dapat dipostulasikan bahwa perubahan kualitas permukiman yang terjadi di Desa Wonokromo dan Wonolelo pasca gempabumi tidak semata-mata ditentukan oleh karakteristik sosial ekonomi penduduk saja namun juga oleh adanya faktor eksternal. Hasil penelitian juga menemukan bahwa di satu sisi bagi penduduk dengan status sosial ekonomi rendah mengalami peningkatan kualitas permukiman setelah gempa karena adanya bantuan dari pihak luar. Sementara itu di sisi lain bagi penduduk dengan status sosial ekonomi tinggi justeru banyak yang tidak mengalami peningkatan kualitas permukiman karena sebelum gempa kualitas pemukimannya sudah relatif baik dan setelah mengalami kerusakan akibat gempa beberapa di antaranya tidak mampu membangun permukiman dengan kualitas yang lebih bagus karena bantuan dari pemerintah sangat terbatas.

Selanjutnya dilakukan analisis statistik inferensial terhadap faktor yang mempengaruhi kualitas permukiman pasca gempabumi dengan menggunakan uji regresi linear berganda untuk setiap desa. Analisis ini bertujuan untuk menjelaskan pengaruh variabel bebas terhadap variabel terpengaruh. Untuk melihat besarnya pengaruh dari variabel bebas terhadap variabel terpengaruh dapat dilihat dari nilai $\mathrm{R}^{2}$. Untuk desa Wonokromo, hasil pengolahan data statistiknya disajikan pada Tabel 2 berikut :

Tabel 2. Model Summary Regresi di Desa Wonokromo

Model Summary (b)

\begin{tabular}{cccccc}
\hline Model & $\mathrm{R}$ & R Sguare & $\begin{array}{l}\text { Adjusted } \\
\text { Square }\end{array}$ & $\begin{array}{l}\text { R } \\
\text { Std.Error of the } \\
\text { Estimate }\end{array}$ \\
\hline 1 & $.909(\mathrm{a})$ & .826 & & .794 & 1.159 \\
\hline
\end{tabular}

$\mathrm{a}=$ Predictors: (Constant) besar bantuan yang diperoleh, jumlah anggota rumah tangga yang masih ditanggung, penghasilan total rumah tangga, pendidikan anggota rumah tangga

$\mathrm{b}=$ Dependent Variable: kualitas permukiman setelah gempa

Dari Tabel 2 dapat dicermati bahwa angka $R$ square di Desa Wonokromo sebesar

$82,6 \%$. Hal ini berarti $82,6 \%$ dari kualitas permukiman pasca gempabumi dapat dijelaskan oleh variabel bebas yaitu jumlah anggota rumah tangga yang masih ditanggung, penghasilan total rumah tangga , pendidikan tertinggi anggota rumah tangga serta bantuan yang diperoleh untuk tahap rehabilitasi dan rekonstruksi permukiman. Sementara itu sisanya $(100 \%-82,6 \%=17,4 \%)$ dijelaskan oleh faktor lain. Tabel 3 berikut menggambarkan persamaan regresi : $\mathrm{Y}=2,43-0,15 \mathrm{x} 1+0,10 \mathrm{x} 2+0,31 \mathrm{x} 3+9,39 \mathrm{E}-0,10 \mathrm{x} 4$

$\mathrm{Y}=$ Kualitas permukiman

$\mathrm{X} 1=$ jumlah anggota rumah tangga yang masih ditanggung

$\mathrm{X} 2$ = penghasilan total rumah tangga

$\mathrm{X} 3=$ pendidikan tertinggi angota rumah tangga

$\mathrm{X} 4=$ besar bantuan yang diperoleh

Dari persamaan regresi pada Tabel 3 diperoleh angka konstanta sebesar 2,436 yang berarti bahwa jika tidak dipengaruhi oleh keempat variabel bebas, maka kualitas permukiman akan terpengaruh sebesar 2,436\%. Koefisien regresi X1 sebesar 0,15 menyatakan bahwa setiap pengurangan 1 orang anggota rumah tangga yang ditanggung akan meningkatkan kualitas permukiman sebesar $0,15 \%$. Koefisien regresi X2 berupa penghasilan total rumah tangga sebesar 0,102 menyatakan bahwa setiap penambahan 1 rupiah penghasilan akan mempengaruhi kualitas permukiman sebesar 0,102\%. Koefisien 
regresi X3 sebesar 0,31\% menyatakan bahwa setiap kenaikan 1 level pendidikan tertinggi anggota rumah tangga maka akan meningkatkan kualitas permukiman sebesar $0,31 \%$. Koefisien regresi X4 berupa bantuan yang diperoleh dari luar keluarga inti akan mempengaruhi kualitas permukiman sebesar 9,39 E-010.

Tabel 3. Persamaan Regresi di Desa Wonolelo

\begin{tabular}{|c|c|c|c|c|c|c|c|}
\hline \multirow[t]{2}{*}{ Model } & \multicolumn{2}{|c|}{$\begin{array}{l}\text { Unstandardized } \\
\text { Coefficients }\end{array}$} & \multirow{2}{*}{$\begin{array}{l}\text { Standardized } \\
\text { Coefficients } \\
\text { Beta }\end{array}$} & \multirow{2}{*}{$\begin{array}{l}\mathrm{t} \\
\text { Tolerance }\end{array}$} & \multirow{2}{*}{$\begin{array}{l}\text { Sig. } \\
\text { VIF }\end{array}$} & \multicolumn{2}{|c|}{$\begin{array}{l}\text { Colleninearity } \\
\text { Statistics }\end{array}$} \\
\hline & B & $\begin{array}{l}\text { Std. } \\
\text { Error }\end{array}$ & & & & B & $\begin{array}{l}\text { Std. } \\
\text { Error }\end{array}$ \\
\hline 1(Constant) & 2,436 & 1,884 & & 1,293 & ,214 & & \\
\hline $\begin{array}{ll}\text { Pendapatan } & \text { total } \\
\text { rumah tangga }\end{array}$ &, 153 & ,305 & ,127 &, 502 & ,623 & ,860 & 1,163 \\
\hline $\begin{array}{l}\text { Pendidikan } \\
\text { anggotinggi } \\
\text { tangga }\end{array}$ & , 102 & ,087 & ,303 & 1,181 & ,255 & ,837 & 1,195 \\
\hline $\begin{array}{l}\text { Jumlah anggota } \\
\text { rumah tangga }\end{array}$ &,- 031 & , 179 &,- 044 &,- 176 & ,863 & ,886 & 1,128 \\
\hline $\begin{array}{l}\text { Besar bantuan yang } \\
\text { diperoleh }\end{array}$ & $\begin{array}{l}9,39 E- \\
010\end{array}$ & ,000 & ,003 & 011 & ,992 & ,837 & 1,195 \\
\hline
\end{tabular}

a Dependent Variable: kualitas permukiman setelah gempa

Berdasarkan uji statistik yang dilakukan dapat diketahui bahwa faktor yang paling mempengaruhi kualitas permukiman di Desa Wonokromo adalah pendidikan tertinggi anggota rumah tangga. Desa Wonokromo yang memiliki ciri kekotaan memiliki tendensi untuk lebih mudah mengakses pendidikan. Hasil wawancara dengan ketua Pokmas Desa Wonokromo mengungkapkan bahwa masyarakat desa tersebut enggan menggunakan prototype rumah contoh karena dianggap terlalu sempit dan tidak sesuai dengan kondisi rumah tangga di desa ini. Anggota rumah tangga dengan pendidikan yang lebih tinggi cenderung membangun rumah dengan dana pribadi, yang diperoleh melalui pinjaman bank. Faktor yang paling tidak mempengaruhi adalah bantuan keuangan yang berasal dari pemerintah, LSM, maupun non anggota keluarga inti. Penduduk Desa Wonokromo yang lebih terdidik dengan tingkat perekonomian yang lebih maju mampu menentukan pilihan terhadap material dan prioritas pembangunan permukiman pasca gempa bumi.

Kondisi perbandingan terhadap Desa Wonolelo dapat dilihat pada hasil uji statistik pada Tabel 4 berikut ini :

Tabel 4. Model Summary Regresi di Desa Wonolelo

Model Summary(b)

\begin{tabular}{cllc}
\hline Model & $R$ & $R$ Square & Adjusted $R$ Square \\
\hline 1 &, $976(\mathrm{a})$ &, 954 &, 928 \\
\hline
\end{tabular}

a Predictors: (Constants), besar bantuan yang diperoleh, jumlah anggota rumah tangga yang masih ditanggung, pendidikan tertinggi anggota rumah tangga, pendapatan total rumah tangga

b Dependent Vaiable: kualitas permukiman setelah gempa

Dari Tabel 4 dapat dicermati bahwa angka $R$ square di Desa Wonolelo sebesar 97,6 $\%$. Hal ini berarti $97,6 \%$ dari kualitas permukiman pasca gempa dapat dijelaskan oleh variabel bebas yaitu jumlah anggota rumah tangga yang masih ditanggung, penghasilan total rumah tangga, pendidikan tertinggi anggota rumah tangga, serta bantuan yang diperoleh untuk tahap rehabilitasi dan rekonstruksi permukiman. Sementara itu, sisanya 
$(100 \%-97,6 \%=2,4 \%)$ dijelaskan oleh faktor lain. Tabel 5 berikut menggambarkan persamaan regresi : $\mathrm{Y}=1,40-0,60 \mathrm{x} 1+1,55 \times 2+0,065 \times 3+7,57 \mathrm{E}-0,8 \times 4$

$\mathrm{Y}=$ Kualitas permukiman

$\mathrm{X} 1=$ jumlah anggota rumah tangga yang masih ditanggung

$\mathrm{X} 2$ = penghasilan total rumah tangga

$\mathrm{X} 3$ = pendidikan tertinggi anggota rumah tangga

$\mathrm{X} 4$ = besar bantuan yang diperoleh

Dari persamaan regresi yang disajikan pada Tabel 5 dapat diketahui bahwa konstanta sebesar 1.407 yang menyatakan bahwa jika tidak dipengaruhi oleh keempat variabel bebas, maka kualitas permukiman di Desa Wonolelo akan terpengaruh sebesar 1,407\%. Koefisien regresi X1 sebesar -0,60 menyatakan bahwa setiap pengurangan 1 orang jumlah anggota rumah tangga yang masih ditanggung (karena tanda-) akan meningkatkan kualitas permukiman sebesar $0,06 \%$. Koefisien regresi X2 berupa penghasilan total rumah tangga sebesar 0,152 menyatakan bahwa setiap 1 rupiah penambahan penghasilan akan meningkatkan kualitas permukiman sebesar $0,15 \%$. Koefisien regresi X3 sebesar 0,65 menyatakan bahwa setiap kenaikan 1 evel pendidikan tertinggi anggota rumah tangga maka akan meningkatkan kualitas permukiman sebesar 0,65\%. Koefisien regresi X4 berupa bantuan yang diperoleh dari luar keluarga inti, akan mempengaruhi kualitas permukiman sebesar 7,57 E-008.

Tabel 5. Persamaan Regresi di Desa Wonolelo

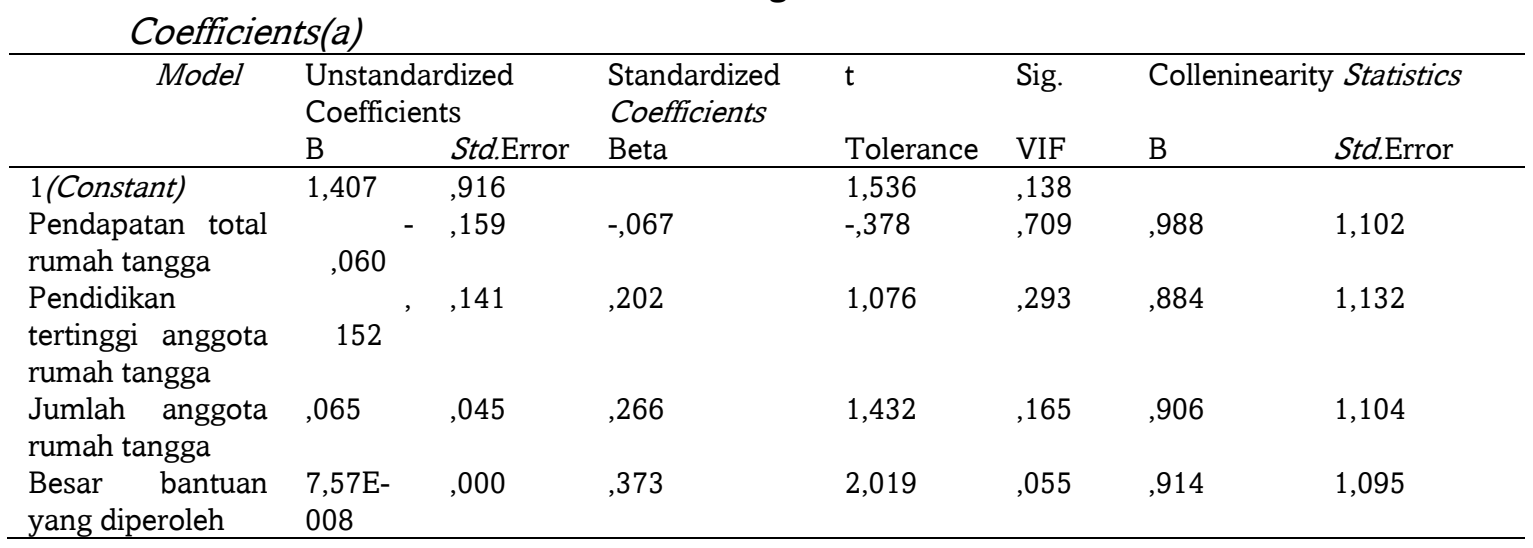

\section{a Dependent Variable: kualitas permukiman setelah gempa}

Faktor yang paling berpengaruh terhadap kualitas permukiman di Desa Wonolelo adalah penghasilan total rumah tangga. Kondisi masyarakat yang sebagian besar masih bekerja di sektor informal menyebabkan mereka tidak memiliki akses terhadap kredit formal. Perbaikan permukiman pasca gempa sangat tergantung pada kemampuan seluruh anggota rumah tangga dalam memperoleh pendapatan untuk rumah tangganya. Untuk selanjutnya dalam penelitian ini juga dianalisis tentang peran modal sosial dalam rehabilitasi dan rekonstruksi permukiman pasca gempa bumi di kedua desa tersebut.

\section{Peran Modal Sosial Dalam Rehabilitasi dan Rekonstruksi Permukiman Pasca Gempa}

Walaupun sampai saat ini belum ada suatu konsensus yang formal tentang sumber dari originalitas serta proses-proses pembentukan modal sosial, namun telah muncul suatu kesepahaman di antara para ahli dan peneliti tentang peran penting modal sosial dalam proses pembangunan. Telah menjadi suatu konsensus umum bahwa untuk 
mendapatkan hasil yang optimal, suatu inisiatif dan proses pembangunan seharusnya mempertimbangkan secara serius akan peran penting dari modal sosial. Sejalan dengan hal tersebut, Narayan (1997 : 19) menyatakan bahwa :

"The rules, the norms, obligations, reciprocity and trust embedded in social relations, social structure and society's institutional arrangements which enable members to achieve their individual and community objective"

Dengan merefer pada pendapat Narayan (1997) tersebut maka variabel modal sosial yang dijadikan subyek penelitian meliputi 4 hal yaitu : norms, reciprocity, trust, dan network. Norms (norma) adalah semua aturan atas perilaku aktivitas sosial-ekonomi warga masyarakat lokal dan melekat dalam jaringan hubungan sosialnya. Reciprocity (timbal balik) adalah semangat timbal balik (reciprocity) melekat kuat sebagai penunjuk bahwa proses kerjasama berlangsung dengan fair. Trust (kepercayaan) adalah interaksi yang didasari persaaan yakin bahwa orang lain akan memberikan respon seperti yang diharapkan, sehingga timbul perasaan aman (percieved safety) ketika berinteraksi dengan orang lain. Network (jaringan antar pelaku) adalah kegiatan yang dilakukan dalam komunitas diikat kuat oleh hubungan-hubungan spesifik antara lain mencakup kekerabatan (kinship), pertetanggaan (neighborship) dan pertemanan (friendship) sehingga semakin menguatkan jaringan antar pelaku.

Modal sosial (social capital) berperan penting dalam proses rehabilitasi dan rekonstruksi permukiman pasca gempa. Hasil penelitian di Tabel 1 menunjukkan bahwa penduduk di Desa Wonolelo mampu meningkatkan kualitas permukimannya meskipun memiliki jumlah pendapatan yang lebih sedikit dari pada penduduk di Desa Wonokromo, serta memiliki akses yang minim terhadap kredit formal.

Dalam penelitian ini juga ditemukan bahwa untuk merehabilitasi dan merekonstruksi rumah pasca gempa bumi yang dapat meningkatkan kualitas permukiman, masyarakat di kedua desa tersebut juga menyediakan dana pribadi. Tabel 6 berikut memberikan gambaran tentang penyediaan dana pribadi dalam peningkatan kualitas permukiman di kedua desa penelitian.

Tabel 6. Penyediaan Dana Pribadi Untuk Merekonstruksi Rumah Di Desa Wonokromo dan Wonolelo

\begin{tabular}{lll}
\hline & Wonokromo & Wonolelo \\
\hline Menjual tanah/aset & $38 \%$ & $63 \%$ \\
$\begin{array}{l}\text { Tipe aset yang dijual } \\
\begin{array}{l}\text { Menyediakan dana dari tabungan } \\
\text { pribadi }\end{array}\end{array}$ Lahan & Sepeda motor/ perhiasan \\
$\begin{array}{l}\text { Jumlah dana pribadi yang } \\
\text { disediakan }\end{array}$ & $>$ Rp 30.000.000 & $37 \%$ \\
Menjadi anggota POKMAS & $69 \%$ & Rp 20.000.000 \\
\hline
\end{tabular}

Sumber : Data Primer, 2010

Dari Tabel 6 dapat dipostulasikan bahwa masyarakat di Desa Wonolelo cenderung memilih untuk menjual aset yang dimiliki seperti sepeda motor atau perhiasan karena tidak memiliki lahan sebagai aset pribadi. Jumlah dana pribadi untuk mendukung perbaikan permukiman yang disediakan juga lebih kecil dibandingkan penduduk di Desa Wonokromo. Menjadi anggota kelompok masyarakat (pokmas) merupakan modal sosial bagi penduduk Desa Wonolelo untuk mengembalikan kondisi permukiman mereka. Karena dimensi network, trust, reciprocity, dan norms akan terbentuk sebagai faktor yang akan sangat membantu pada proses rehabilitasi dan rekonstruksi. 
Tabel 7. Peran Modal Sosial Dalam Proses Pembangunan Permukiman Pasca Gempa Di Desa Wonokromo dan Wonolelo

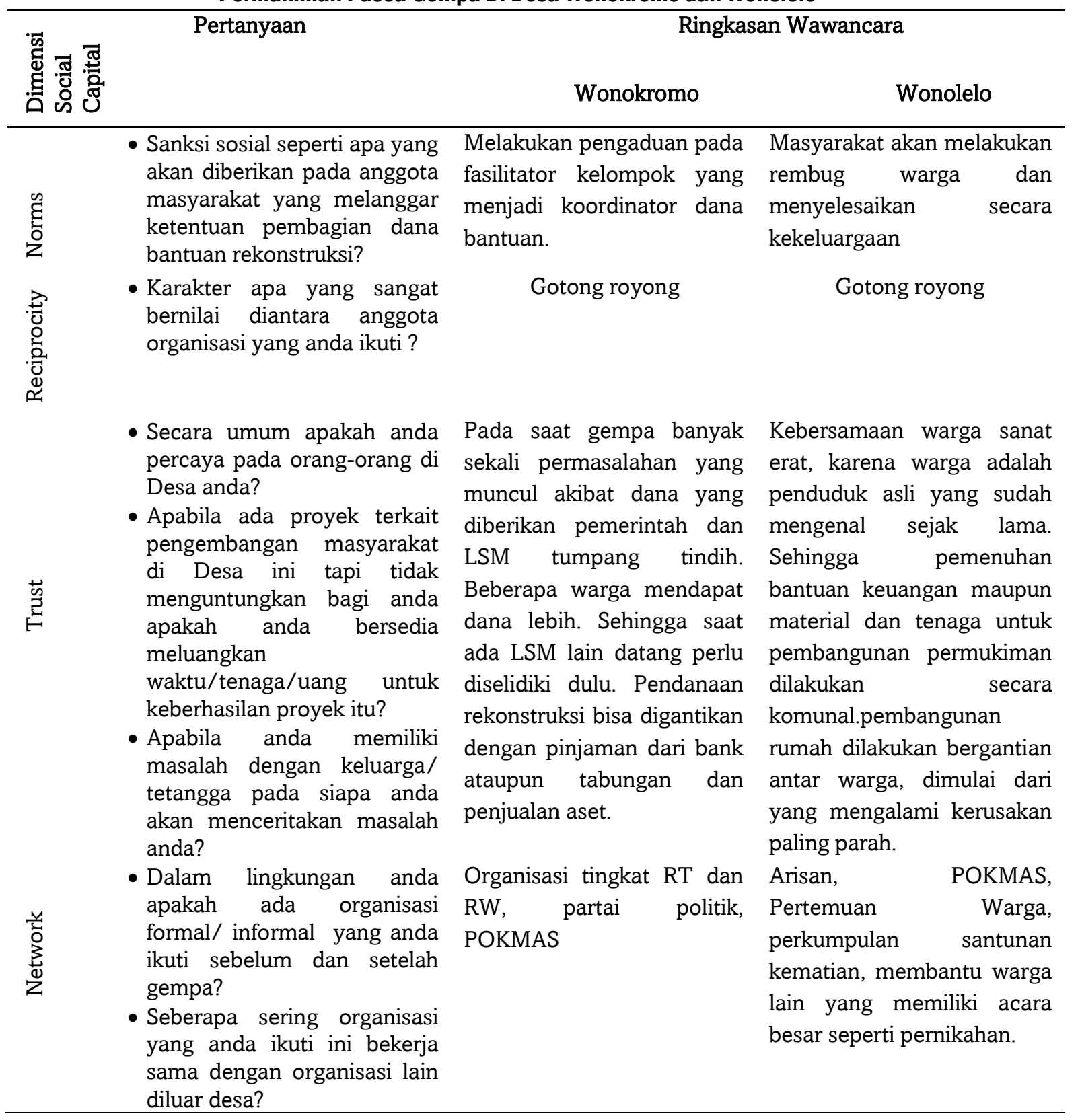

Sumber : Data Primer, 2009

Hasil penelitian ini sejalan dengan temuan dalam penelitian Durkeim (1973), (Fukuyama (1995a), Fukuyama (1995b), Fukuyama (2000), Damayanti (2006), Hasbullah (2006), dan Sakamoto dan Yamori (2009). Deskripsi peran modal sosial berdasarkan dimensinya disajikan pada Tabel 7. Dimensi modal sosial sangat berperan dalam peningkatan kualitas permukiman di Desa Wonolelo. Kegiatan gotong royong sudah merupakan adat kebiasaan bagi penduduk Desa Wonolelo jauh sebelum terjadi gempabumi tahun 2006. Kegiatan gotong royong ini tetap eksis di Desa Wonolelo setelah terjadi gempa bumi. Kegiatan gotong royong selama ini terekspesikan dalam berbagai aktivitas mulai dari yang bersifat (1) sosial, (2) sosial dan personal, serta (3) personal yang diwujudkan dalam 
bentuk pertukaran (exchange). Ditinjau dari bentuk yang dikerjasamakan, gotong royong bisa mencakup material, tenaga, uang dan social spirit. Secara umum aktivitas gotong royong memiliki tema sentral sebagai mutual help antar anggota masyarakat yang mana masing-masing pihak terlibat saling memberikan kontribusi dan sebagai reward-nya mereka mendapatkan gain dari aktivitas yang dikerjasamakan.

Pada saat kesulitan muncul pada komunitas tersebut, maka semangat timbal balik (reciprocity) muncul. Hal ini menjadi indikator bahwa proses kerjasama yang berlangsung sebelum gempa berjalan dengan fair. Dalam prakteknya timbal balik memiliki spektrum yang fleksibel dari timbal balik yang sangat ketat (strict reciprocity) sampai dengan timbal balik yang longgar (non-strict reciprocity). Strict reciprocity pada kasus Desa Wonolelo muncul ketika masyarakat tidak mampu mengakses kredit formal. Modal sosial yang sudah ditanamkan akan dituai berupa pinjaman informal dari tetangga maupun keluarga dekat yang tidak terkena dampak gempa bumi.

Bukan tidak mungkin dalam kasus-kasus tertentu terjadi ketidakseimbangan antara kontribusi dan gain yang diperoleh pihak terlibat dalam jangka panjang, namun karena warga masyarakat masih memegang prinsip generousity, hal itu diterima sebagai hal yang biasa dengan kebesaran hati. Semangat kesepadanan, dan timbang rasa memungkinkan anggota masyarakat di Desa Wonolelo memperoleh gain yang lebih besar dibandingkan dengan kontribusi yang diberikan kepada kelompoknya. Hasil penelitian ini sejalan dengan apa yang pernah ditemukan oleh Narayan (1997).

\section{Kesimpulan}

Perubahan kualitas permukiman yang terjadi di daerah penelitian pra dan pasca gempabumi dipengaruhi oleh faktor internal dan faktor eksternal. Faktor internal berupa pendidikan tertinggi anggota rumah tangga mempunyai peran yang paling tinggi dalam mempengaruhi perubahan kualitas permukiman di Desa Wonokromo. Sementara itu faktor internal yang paling mempengaruhi perubahan kualitas permukiman di Desa Wonolelo adalah pendapatan total rumah tangga.

Di samping faktor internal tersebut, penelitian ini juga menyimpulkan bahwa faktor eksternal yang berasal dari luar yang berupa intervensi dari pihak luar juga memiliki pengaruh terhadap kualitas permukiman. Salah satu faktor eksternal yang dimaksud dalam penelitian ini adalah modal sosial. Minimnya akses terhadap kredit formal untuk memenuhi kebutuhan material pembangunan permukiman tidak menjadi penghalang warga untuk meningkatkan kualitas permukiman karena mereka masih memiliki modal sosial. Peningkatan kualitas permukiman terjadi di Desa Wonolelo membuktikan bahwa modal sosial atau social capital yang terdiri dari norms, trust, reciprocity, dan networ mempunyai peran penting dalam proses rehabilitasi dan rekonstruksi pasca gempa bumi. Dengan demikian, sekaligus dapat disimpulkan bahwa dalam konteks kejadian bencana terdapat hubungan yang tipikal antara kualitas permukiman dengan faktor eksternal yang berupa modal sosial.

\section{Ucapan Terima Kasih}

Makalah ini merupakan bagian dari Laporan Penelitian yang merupakan kerjasama antara Nagoya University Jepang, Lembaga Ilmu Pengetahuan Indonesia (LIPI) Indonesia, dan Universitas Gadjah Mada Indonesia yang dilaksanakan pada tahun 2009-2011. Untuk itu penulis menyampaikan ucapan terima kasih yang tak terhingga kepada The Graduate School of Environmental Studies Nagoya University Japan yang telah membiayai kegiatan penelitian ini. 


\section{Daftar Pustaka}

Damayanti, Sari. 2006. Modal Sosial pada Komunitas Penghuni Perumahan dengan Studi Kasus Perum Minomartani. Tesis. Fakultas Geografi UGM. Yogyakarta.

Daryono. 2012. Indeks Kerentanan Seismik Berdasarkan Mikrotremor Pada Setiap Satuan Bentulahan di Zona Graben Bantul. Disertasi. Program Studi S3 Geografi Fakultas Geografi Universitas Gadjah Mada.

Durkheim, Emile. 1973. Moral Education: Study in the Theory and Application of the Sociology of Education. New York: Free Press.

Fukuyama, F. 1995a. Trust: The Social Virtues and The Creation of Prosperity. New York: Free Press. 1995b. Social Capital and The Global Economy. Foreign Affairs, 74(5), 89-103.

2000. Social Capital and Civil Society. International Monetary Fund Working Paper, WP/00/74, 18.

Hasbullah, J., 2006. Sosial Kapital: Menuju Keunggulan Budaya Manusia Indonesia.Jakarta: MR-United Press

Narayan. 1997. Voice of the Poor: Poverty and Social Capital in Tanzania. World Bank,. Washington. DC 20433 USA.

Primayodanti, Kiti.2008. Kualitas Permukiman Non Mogran dan Migran Pasca Gempa Bumi 27 Mei 2006 di Desa Banyuraden Kecamatan Gamping Kabupaten Sleman. Tesis. Fakultas Geografi UGM. Yogyakarta.

Romadona, Aditya Lia. 2008. Evaluasi Pemulihan Lingkungan Permukiman Kota Pasca Gempa Bumi 2006. Tesis. Fakultas Geografi UGM. Yogyakarta.

Sakamoto,Mayumi. dan Katsuya Yamori. 2009. A Study of Life Recovery and Social Capital regarding Disaster Victims- A Case Study of Indian Ocean Tsunami and Central Java Earthquake Recovery. Journal of Natural Disaster Science, Volume 31, Number 2, 2009, pp13-20.Japan

Solikhah, Kiki Z dan Dewi Larasati. 2008. Model Proses Produksi Rumah Massal Untuk Rekonstruksi di Indonesia Sebagai Pertimbangan Untuk Perencanaan Kota dan Kawasan Pasca Bencana (Kasus Pasca Bencana di Aceh, Yogyakarta, \& Pangandaran). Makalah Seminar. Jurusan Arsitektur Institut Teknologi Bandung.Bandung

Suryanto. 2012. Hubungan Antara Karakteristik Wilayah, Persepsi dan Perilaku Untuk Willingness to Pay (WTP) Terhadap Resiko Bencana Gempa Bumi di Kabupaten Bantul Propinsi DIY. Disertasi. Program Studi S3 Ilmu Lingkungan Sekolah Pascasarjana.

Syahyudesrina. 2008. Perubahan Lingkungan Permukiman Pasca Tsunami dan Implikasinya Kebijakan Untuk Penataan Kawasan Kota Dan Permukiman. Tesis. Program Studi S2 Ilmu Lingkungan Fakultas Geografi UGM. Yogyakarta.

Ritohardoyo. 2000. Hand Out Geografi Permukiman. Fakultas Geografi UGM. Yogyakarta.

Yunus, Hadi Sabari. 1989. Subject Matter dan Metode Penelitian Geografi Permukiman. Fakultas Geografi UGM. Yogyakarta. 